\title{
Counter-Insurgency and Human Rights Violations in Nigeria
}

\author{
Akanni, Nnamdi Kingsley \\ Ph.D, Member, Governing Council, Rivers State University, Port Harcourt, Rivers State
}

\begin{abstract}
In the conduct of counterinsurgency campaigns by government forces, human rights of the citizens of the States where insurgents operate are usually violated. For instance in the prosecution of the Boko Haram counterinsurgency in North-east Nigeria, the Nigerian military, Multinational Joint Task Forces and the Civilian Joint Task Force have been accused of committing gross human rights abuses and serious violations of international humanitarian law resulting in on-going casualties and further destruction of property. This paper examines the violations of human rights which take place in the conduct of counter-insurgency campaigns in any State, including Nigeria. The paper argues that in spite of the avalanche of international and domestic laws which regulate the conduct of warfare, particularly the rules of International Humanitarian Law (IHL) and International Human Rights (IHR) law, Nigerian security operatives and their international partners engaged in counterinsurgency have continued to commit gross abuses of human rights in the North-east Nigeria. The paper further argues that it is not possible to launch a successful counter-insurgency campaign without committing gross violations of basic human rights such as life, dignity of human person, liberty, private and family life, association and assembly as well as right to freedom of movement, if the rules of engagement and international best practices are observed religiously. In view of these findings, the paper recommends that government forces engaged in counterinsurgency should observe strictly the IHL rules and rules of engagement for military personnel as well as investigation and prosecution of culprits to serve as deterrent to violators.
\end{abstract}

Keywords: Counter-insurgency, Human, Rights, Violations, Nigeria.

DOI: $10.7176 / J L P G / 85-02$

Publication date:May $31^{\text {st }} 2019$

\section{Introduction}

All over the world, effective counter-insurgency requires extraordinary measures and these extraordinary measures may lead to abridgement of certain human rights. During counter-insurgency campaigns, it is often a usual practice to declare state of emergency, otherwise known as emergency rule. Ramraj and Thiruvengadam define emergency powers as coercive powers, claimed or invoked by or on behalf of the State, the purpose of which is to address a serious threat (usually to persons, property or social order) which, in the view of those who invoke it, cannot be addressed by ordinary law. ${ }^{1}$ In the course of fighting the Boko Haram insurgents, former President Goodluck Jonathan proclaimed emergency rule in the three North-east states of Borno, Adamawa and Yobe. ${ }^{2}$ By the declaration, the Chief of Defence Staff was directed to deploy more troops to the affected States. The security agencies deployed were given the carte blanche to arrest and detain suspects, to take possession and control of any building or structure used for terrorist activities, to lock down any area of operation by insurgents, to conduct searches and to apprehend and prosecute persons in illegal possession of weapons. ${ }^{3}$

The enactment of the Terrorism (Prevention) Act (TPA) 2011 elicited concerns among the populace about the possibility of human rights abuses that may occur due to the wide and sweeping powers given to the security agencies without serious judicial control. ${ }^{4}$ For example, section 25 of the Act authorises the National Security Adviser (NSA) or the Inspector General of Police (IGP) to enter and search any place, persons or vehicle without warrant where he has reason to suspect that any of the terrorism offences created under the Act was being committed. ${ }^{5}$ Furthermore, the NSA or IGP can search, detain and arrest any person upon reasonable suspicion of the person having committed or about to commit an offence under Act.

It cannot be disputed that the use of emergency powers in the fight against insurgency is a global trend. Besides, the declaration of state of emergency in the north-east has constitutional backing. ${ }^{6}$ However, security agencies should endeavour to preserve the basic human rights during counter-terrorism operations in the country. ${ }^{7}$ Human rights are basic and inalienable under the law. Derogation from and restriction on fundamental rights are

V V Ramraj and A K Thiruvengadam, Emergency Powers in Asia: Exploring the Limits of Legality (OUP 2008$) 2$.

'Breaking News: Jonathan Declares State of Emergency in Borno, Yobe and Adamawa State', Sahara Reporters (New York, 14 May 2013 )

$<$ http://www.saharareporters.com/2013/05/14/breaking-news.jonathan-declares-state-of-emergency-borno-yobe-and-adamawa-state>

accessed 21 February 2019.

Ibid.

A Omolaye-Ajilaye, 'Legal Framework for the Prevention of Terrorism in Nigeria' [2015] (2) NIJ Law Journal 38.

Section 25 in TPA 2011 has now been substituted in TPA 2013.

1999 Constitution, Ss 45(2) and 305.

O W Igwe, 'Terrorism, the Rule of Law and the Nigerian Nation' $<$ http://www.researchgate.net/profile/Ow/gwe/publication/275271581_TERRORISM_THE_RULE_OF_LAW_AND_THE_NIGERIA

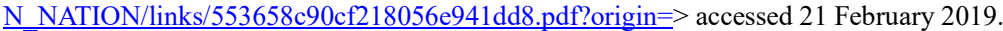


permitted only in the most extraordinary of circumstances. Thus, the TPA and other terrorism laws should balance the need for the preservation of law and order, the protection of lives and property and to defend the territorial integrity of the country against the citizens' rights to freedom from torture, inhuman and degrading treatment, personal liberty, private and family life and fair hearing. Against this background, this paper seeks to examine the human rights violated in Nigeria and neighbouring countries during the counter-insurgency campaigns carried out in the north-east. However, before doing that, it will be more appropriate to examine briefly the meaning of the terms 'insurgency' and 'insurgency'.

\section{Meaning of the Term 'Insurgency'}

The term 'insurgency' has elicited more confusions than it has definition. In fact, some scholars have confused insurgency with 'terrorism' or 'guerilla warfare'. Perhaps, a convenient starting point for explicating the concept 'insurgency' would be to first examine what it is not. Insurgency is not terrorism or conventional war ${ }^{1}$ for example, though it shares with them some similarities such as the use of force or guerrilla tactics to achieve an end which is often political. Basically, the difference between insurgency and terrorism lies in the scope and magnitude of violence. While for instance, terrorism rarely brings about political change on its own, insurgency attempts to bring about change through force of arms. Similarly, terrorists often apply a wide range of damages when compared to insurgents.

The Oxford Dictionary defines insurgency as "an armed rebellion against a constituted authority (for example, an authority recognized as such by the United Nation) when those taking part in the rebellion are not recognized as belligerent" ${ }^{2}$. The United States Department of Defence ${ }^{3}$, defines it as an organized movement that has the aim of overthrowing a constitute government through subversive means and armed conflict. The implication of this definition is that insurgent groups employ clandestine and unlawful means towards achieving an end, which could be political, religious, social or even ideological. As a result, Siegel ${ }^{4}$ argued that the goal of insurgency is to confront and overthrow an existing government for the control of power, resources or for power sharing.

According to Kilcullen ${ }^{5}$, "insurgency is a struggle to control a contested political space, between a state or a group of states or occupying powers, and one or more popularly based, non-state challengers." Nonetheless, Kilcullen drew a line between classical and contemporary insurgencies. He said while the latter seek to replace the existing order, the former sometimes strive for the expulsion of foreign invaders from their territory or seek to fill an existing power vacuum.

Colonel Dennis Drew" ${ }^{6}$, defined it as "an insurgency is nothing more than an armed revolution against the established political order". He went to further to add that insurgencies are internal affairs and the insurgents are self-sustaining.

According to the US Army-Marine Corps Counterinsurgency Field Manual (FM 3-24), insurgency as an organized, protracted politico-military struggle designed to weaken the control and legitimacy of an established government, occupying power, or other political authority while increasing insurgent control.

\section{The Concept of Counter-Insurgency}

Counterinsurgency (COIN) is just the opposite of insurgency. COIN involves a combination of measures undertaken by the legitimate government of a country to curb or suppress an insurgency taken up against it. So while insurgents for instance try to erase or overthrow the existing political authority in order to establish theirs, the counter-insurgent forces try to reinstate the existing political structures as well as reduce or annihilate the usurping authority of the insurgents ${ }^{7}$.

Counterinsurgents hold monopoly of violence, legitimacy as well as other material resources often exclusively reserved for States. These factors also emphasise the need for counterinsurgents to uphold law and order, something that technically limits their potential action in the fight against insurgencies. On the other hand, insurgents are characterised by lack of resources or power as well as a general lack of responsibility in destroying State properties while launching their grievances ${ }^{8}$. Insurgents are consequently much freer to violate State laws or the social norms, target civilians as well as decide where and when the conflict begins.

On its own part, the US Army-Marine Corps Counterinsurgency Field Manual (FM 3-24) defines

\footnotetext{
${ }^{1}$ S E Liolio, 'Rethinking Counterinsurgency: A Case Study of Boko Haram in Nigeria' (Unpublished M.A. Thesis, European Peace University, Austria 2013) 33.

${ }^{2} \mathrm{~S}$ E Liolio (n 8) 34

${ }^{3}$ P Hellesen, 'Counterinsurgency and Its Implications for the Norwegian Special Operations Forces' (Unpublished Thesis for the Naval Post Graduate School, Monterey, California, USA 2008)14.

${ }^{4}$ J Siegel, Criminology: Theories, Patterns and Typologies (11 $11^{\text {th }}$ edn, Belmount, CA: Wadsworth Cengage Learning 2007) 328.

${ }^{5}$ D Kilcullen, "Three Pillars of Counterinsurgency" in Government Counterinsurgency Conference held in 2006 at Washington D.C. $<$ http://www.au.af.mil/au/awc/awegate/uscoin3pillars of counterinsurgency.pdf $>$ accessed 19 January2019.

${ }^{6}$ D Drew, 'Insurgency and Counterinsurgency: American Military Dilemmas and Doctrinal Proposals' in Report No. AU-ARI-CP-88-1 (1988).

${ }^{7} \mathrm{~S}$ E Liolio (n 8) 43

${ }^{8}$ S E Liolio (n 8) 43
} 
counterinsurgency as a "military, paramilitary, political, economic, psychological, and civic actions taken by a government to defeat insurgency." Like the case of insurgency, this definition of counterinsurgency has also witnessed slight moderation or changes. The 2009 Joint Publication 3-24: Counterinsurgency Operations, defines COIN as a "comprehensive civilian and military efforts taken to defeat an insurgency and to address any core grievances ${ }^{2}$. Furthermore, it noted that "COIN is primarily political and incorporates a wide range of activities, of which security is only one." While this new definition included a key point of addressing core insurgents' grievances; it fails to reflect the different facets of COIN operations. To borrow the words of the US Government then, "effective counterinsurgency integrates and synchronizes political, security, legal, economic, development, and psychological activities to create a holistic approach aimed at weakening the insurgents while bolstering the government's legitimacy in the eyes of the population." 3

Counterinsurgency is defined as 'those military, paramilitary, political, economic, psychological and civic actions taken by a government to defeat an insurgency. ${ }^{4}$ David Kilcullen ${ }^{5}$ says counterinsurgency is best defined by as "an umbrella" term that describes the complete range of measures that government takes to defeat insurgencies" According to the U.S. Government Counterinsurgency Guide ${ }^{6}$, counter-insurgency or counterinsurgency (COIN) "may be defined as comprehensive civilian and military efforts taken simultaneously defeat and contain insurgency and address the its root causes.

The current Department of Defense definition of counterinsurgency reads as follows: "Those military, paramilitary, economic, psychological, and civic actions taken by a government to defeat insurgency. " While more expansive than the doctrinal definition of insurgency in its acknowledgement of political and economic components, its emphasis on defeating an enemy betrays a military bias. Additionally, it does little to aid in understanding the nature of counterinsurgency or its expected end state. Given the nature, characteristics, and strategy of insurgency, any definition of counterinsurgency must acknowledge the complexity of the conflict. For these reasons, the following definition of counterinsurgency is offered:

Counterinsurgency is an integrated set of political, economic, social, and security measures intended to end and prevent the recurrence of armed violence, create and maintain stable political, economic, and social structures, and resolve the underlying causes of an insurgency in order to establish and sustain the conditions necessary for lasting stability ${ }^{8}$.

This definition both acknowledges the causes and dynamics of insurgency and the three-dimensional complexity of dealing with them and places military and security operations firmly within the wider context of the conflict. Perhaps most important, it also establishes the end-state of successful counterinsurgencies ${ }^{9}$. In that sense, it is a prescriptive definition; understanding counterinsurgency must begin with comprehending not only its components, but its ultimate objective.

\section{Nature of Counter-Insurgency}

Counterinsurgency is those military, paramilitary, economic, psychological and civil actions taken by a government to defeat an insurgency. In a counterinsurgency, Host Nation forces and partners operate to defeat armed resistance, reduce passive opposition, and establish or re-establish the legitimacy of the Host Nation's government. Counterinsurgency is a proactive approach involving all elements of national power; even down to the tactical level. COIN operations strive to achieve unity of effort amongst many joint, interagency, intergovernmental, and multinational organizations. COIN includes tactical planning; intelligence development and analysis; training; materiel, technical, organizational assistance; advice; infrastructure development; tacticallevel operations; and information engagement. US forces often lead the US government's counterinsurgency efforts because the US military can quickly project a counterinsurgent force and sustain not only its force but also other agencies ${ }^{10}$

Counterinsurgency is a complex effort that integrates the full range of civilian and military agencies. It is often more population-centric (focused on securing and controlling a given population or populations) than enemycentric (focused on defeating a particular enemy group). This does not mean that counterinsurgency is less violent

\footnotetext{
${ }^{1}$ H David H and F James, 'FM 3-24 Counterinsurgency'[2006] (3-33.5) Marine Corps Warfighting Publication; 1-2.

${ }^{2} \mathrm{~S}$ E Liolio (n 8) 34

${ }^{3}$ Guide to the Analysis of Insurgency' (2012) published by the US Government1.

${ }^{4} \mathrm{~S}$ Vrooman 'A Counterinsurgency Campaign Plan Concept: The Galula Compass' in A Monograph, US Army School of Advanced Military Studies, United States Army Command and General Staff College Fort Leavenworth, Kansas (AY 04-05).

${ }^{5}$ D Kilcullen (n 12).

${ }^{6}$ Bureau of Political-Military Affairs, Department of State (2009).

${ }^{7}$ Joint Publication 1-02, DoD Dictionary of Military and Associated Terms dated 12 Apr 2001 (amended to 25 August 2005).

${ }^{8}$ S E Liolio (n 3) 34

${ }^{9}$ Ibid.

${ }^{10} \mathrm{~W}$ George, Tactics in Counterinsurgency (Washington D.C Headquarters Department of the Army 2009$) 10$.
} 
than any other conflict: on the contrary, like any other form of warfare it always involves loss of life. It is an extremely difficult undertaking, is often highly controversial politically, involves a series of ambiguous events that are extremely difficult to interpret, and often requires vastly more resources and time than initially anticipated. In particular, governments that embark upon COIN campaigns often severely underestimate the requirement for a very long-duration, relatively high-cost commitment (in terms of financial cost, political capital, military resources and human life). ${ }^{1}$

The capabilities required for counterinsurgency may be very similar to those required for peacekeeping operations, humanitarian assistance, stabilization operations, and development assistance missions. However, counterinsurgency differs from peacekeeping operations in this regard; indeed, this is a key point. In peacekeeping operations, combat is not expected and the goal is an absence of violence. In counterinsurgency, such an absence may actually mask insurgent preparations for combat. ${ }^{2}$ The intent of a counterinsurgency campaign is to build popular support for a government while marginalizing the insurgents: it is therefore fundamentally an armed political competition with the insurgents. Consequently, control (over the environment, the population, the level of security, the pace of events, and the enemy) is the fundamental goal of counterinsurgency, a goal that distinguishes it from peace operations or humanitarian intervention. Within these broad characteristics, the specific nature of any particular counterinsurgency campaign arises from the complex interaction of three key factors: the characteristics of the environment (physical, economic, political and human) in which it takes place; the nature of the insurgent group (or groups); and the nature of the counterinsurgent government and its security forces. The purpose of counterinsurgency is to build popular support for a government while suppressing or co-opting insurgent movements. ${ }^{3}$

\section{Approaches to Counterinsurgency}

Different approaches have emerged towards countering insurgency. Some of them include:

\subsection{The Enemy-Centric Approach}

This approach conceives COIN as a contest with an organized enemy, and thus emphasizes defeat of the enemy as its primary objective, while viewing other mechanisms as secondary. In other words, the focus here is on the complete annihilation of the insurgents or their guerrilla formations and cadres while minimising the significance of nation-building as well as measures to gain popular support. There are also "many variants within this approach, including "soft" vs. "hard," direct vs. indirect, violent vs. non-violent, and decapitation vs. marginalization strategies." This approach can be summarized as "first defeat the enemy, and all else will follow." In modern times, this approach is often not discussed but it is applied in COIN operations. It has also been said that if this approach is applied to its fullest, it "might work against incipient insurgencies that are led or centrally controlled by a particularly charismatic or powerful individual."

\subsection{The Population Centric Approach}

Unlike the first approach, the population-centric approach focuses on protecting the population and maintaining or winning its support. Although direct military confrontation might be needed in defeating the insurgents, it is not seen here as the primary objective which is to win the supports of the population. This approach can be summarized as "first protect and support the population, and all else will follow." 90 There are more theorists supporting the population-centric approach than they are with the enemy-centric approach. The U.S. style of COIN embedded in the 2006 FM 3-24 also follows this approach to whose credits. ${ }^{5}$

\subsection{Carrots and Sticks, Hearts and Minds}

Another major approach to counterinsurgency is the older and more famous "hearts and minds" strategy which operates by a somewhat different logic, focusing on "the problems of modernization and the insurgent need for popular support." As Rand explains, the aim was to rebuild public confidence in the government by instituting reforms, reducing corruption, and improving the population's standard of living. ${ }^{6}$

\subsection{Weed and Seed: Clear-Hold-Build}

Weed and Seed was conceived in 1991, and gained prominence a year later as part of the federal response to widespread rioting after the acquittal of four Los Angeles cops who had been videotaped beating Black motorist

\footnotetext{
${ }^{1}$ 'Counterinsurgency- An Introduction'. <https://jadl.act.nato.int/NATO/data/NATO/lm_data/lm_8422/11689/index.html> assessed on 21 February 2019

${ }^{2}$ Ibid.

${ }^{3}$ 'Counterinsurgency- An Introduction'. <https://jadl.act.nato.int/NATO/data/NATO/lm data/lm 8422/11689/index.html> assessed on 21 February 2019

${ }^{4} \mathrm{C}$ Gompert and Others, War by Other Means: Building Complete and Balanced Capabilities for Counterinsurgency (Santa Monica: Rand 2008) 12 .

${ }^{5}$ Ibid.

${ }^{6} \mathrm{Ibid}, 25$.
} 
Rodney King. Since that time, it has been implemented in over 300 neighbourhoods nationwide. ${ }^{1}$

The Department of Justice describes the project: ${ }^{2}$

The Weed and Seed strategy is based on a two pronged approach:

1. Law enforcement agencies and criminal justice officials cooperate with local residents to 'weed out' criminal activity in the designated area.

2. Social service providers and economic revitalization efforts are introduced to 'seed' the area, ensuring long-term positive change and a higher quality of life for residents."

In terms of strategy, Weed and Seed closely resembles the military's "Clear-Hold-Build." As FM 3-24 elaborates: "Create a secure physical and psychological environment. Establish firm government control of the populace and area. Gain the populace's support". ${ }^{3}$

Clearing and holding refer to the removal and exclusion of hostile elements. Building, on the other hand, means both, literally, repairing infrastructure and, more metaphorically, gaining trust and winning support. However, even building includes an element of force: ${ }^{4}$

Progress in building support for the HN [Host Nation] government requires protecting the local populace... To protect the populace, HN security forces continuously conduct patrols and use measured force against insurgent targets of opportunity. . . Actions to eliminate the remaining covert insurgent political infrastructure must be continued.

The domestic analogy is pretty straightforward. One police chief described the role of paramilitary units in his community policing strategy: ${ }^{5}$

The only people that are going to be able to deal with these problems are highly trained tactical teams with proper equipment to go into a neighbourhood and clear the neighbourhood and hold it; allowing community policing officers to come in and start turning the neighbourhood around. ${ }^{6}$

In such campaigns, the relationship between community policing and militarization is especially clear. They are not competing or contradictory approaches. They work together, simultaneously or in series. One does the weeding; the other, the seeding. The implications are not lost on those subject to this sort of campaign. "They're gunning for us," Omari Salisbury, a Seattle teenager, said when he heard about Weed and Seed. "They're gunning for Black youth". ${ }^{7}$

\section{Human Rights Violations during Counter-Insurgency in Nigeria}

In countering insurgency in Nigeria, security operatives ${ }^{8}$ have unleashed brutal revenge attacks on innocent civilians and insurgents who are according to the Nigerian Constitution are presumed innocent until proven otherwise. Citizens suffer constant human rights violations most times there is a countering operation by the security. These violations include right to life, right to freedom of movement and others. States have an obligation to respect and protect the right to life of individuals under their jurisdiction from attacks by armed groups. Such an obligation includes taking measures to prevent the commission of offences, investigating human rights abuses and international humanitarian law violations promptly, thoroughly and independently and prosecuting those found responsible, providing adequate and effective remedies, and preventing the recurrence of violations. ${ }^{9}$ The Niger and Nigeria have declared a state of emergency in response to the attacks conducted by Boko Haram. ${ }^{10}$

Measures taken pursuant to derogations are lawful to the extent that they comply with the conditions set out in international human rights law. Article 4 of the International Covenant on Civil and Political Rights provides for the possibility for States to adjust temporarily certain obligations under the treaty in time of "public emergency which threatens the life of the nation" providing a number of conditions are met, in particular that measures are limited to the extent strictly required by the exigencies of the situation, ${ }^{11}$ that adequate safeguards are in place to

${ }^{1}$ K Williams, 'The Other Side of the COIN: Counterinsurgency and Community Policing' [2011] (3) A Journal for Social Movement; 97.

${ }^{2}$ Ibid.

${ }^{3}$ Ibid.

${ }^{4}$ Ibid, 98.

${ }^{5} \mathrm{~K}$ Williams (n 32) 98.

${ }^{6}$ B Kraska and E Kappeler., 'Militarizing American Police: The Rise and Normalization of Paramilitary Units' in V E Kappeler (ed), The Police and Society: Touchstone Readings (Prospect Heights: Waveland Press 1999) 473.

${ }^{7}$ D Lilly, 'City Urged to Bury Weed and Seed Plan', SeattleTimes (Seattle, 27 March 1992).

${ }^{8}$ A S Odomovo, 'Insurgency, Counterinsurgency and Human Rights Violations in Nigeria' [2014] (3) The Age of Human Rights Journal, 6.

${ }^{9}$ United Nations Human Rights Council, 'Violations and Abuses Committed by Boko Haram and the Impact on Human Rights in the Countries Affected'< $<$ https://www.ohchr.org/EN/HRBodies/HRCRegularSessions/.../A- HRC-30-36_en// accessed 20 February 2019.

${ }^{10}$ Nigeria declared Boko Haram a terrorist organization on 4 June 2013. It declared a state of emergency in the States of Adamawa, Borno and Yobe on 20 May 2013, which was extended several times, most recently on 13 May 2014 for a period of six months.

${ }^{11}$ This obligation reflects the principle of proportionality, which is common to derogation and limitation powers. Any measures thus taken need to be in genuine response to the situation, aimed at the restoration of a constitutional order respectful of human rights and be fully justified by the circumstances. Therefore, the mere fact that derogating from a specific provision may of itself be justified by the exigencies of the situation does not obviate the requirement to demonstrate the necessity of the concrete measures taken pursuant to the derogation. 
protect against arbitrary and disproportionate interference with human rights, ${ }^{1}$ and that procedural safeguards are never limited in a manner that would circumvent the protection of non-derogable rights. ${ }^{2}$

\subsection{Killing of Civilians during Counter-Insurgency Operations}

One of the gravest violations of human rights committed by government security forces during counter-insurgency operations is the killing of civilians. The violation of the right to life of the Nigerian people, particularly in the north-east has been a key feature of the government's onslaught against the Boko Haram insurgency. For instance, the Office of the High Commissioner on Human Rights (OHCHR) documents that attacks by security forces causing a high number of civilian casualties have been reported, most notably in Baga, Nigeria, in April 2013, where civilians were reportedly shot by security forces and 642 people were displaced. ${ }^{3}$ Investigations into the event by reliable national sources determined that cases of extrajudicial and summary executions, torture, arbitrary detention, enforced disappearance and rape had been committed by national security forces. According to the sources, the extent to which the allegations were founded could not be verified. ${ }^{4}$ OHCHR was also informed of other allegations, including of summary executions, torture, arbitrary detention and prolonged incommunicado and enforced disappearance committed by the national security forces in Baga and Bama, as well as of detainees being starved and held without water in overcrowded cells in an army barrack, leading to death. The full extent and timeline of the allegations could not, however, be verified. ${ }^{5}$

Similar civilian casualties were recorded in Cameroon where witnesses interviewed by OHCHR referred to killings by defence forces during raids that followed either Boko Haram attacks or tip-offs from so-called "vigilante" group members. According to witness information received by OHCHR, the Cameroonian army reportedly killed more than 70 people during the raids, the greatest number of casualties being in Bia, Double and Magdeme villages. Some of the deceased were reportedly buried in a mass grave in Mindif, an area that was used as a shooting site for the rapid response battalion. ${ }^{6}$

\subsection{Enforced Disappearances, Arrests, Detention and Ill-treatment of Detainees}

In Nigeria, OHCHR received confirmation that, in areas affected by Boko Haram, young men were not only exposed to the risk of being targeted by Boko Haram but also of being arbitrarily arrested and detained if suspected of being members of Boko Haram by the army, the police or civilian vigilante groups. One victim recounted how he had been mistaken for a member of Boko Haram and detained by the military in Yola, State of Adamawa. He also reported concerns regarding ill-treatment and conditions in detention, which lead to an average of five deaths every day in the cell where suspected Boko Haram detainees were held and reportedly regularly beaten. Witnesses informed OHCHR that Boko Haram suspects were deprived of food and water, and that some drank each other's urine. OHCHR also received information on allegations of arbitrary detention and cases of torture in the State of Borno. Once access to detention facilities is granted by the authorities, it will be possible to collect additional information and to verify these allegations. ${ }^{7}$

Cases of indiscriminate arrests, detention and maltreatment of persons suspected to be Boko Haram members or of working in close cahoots with the insurgents were not confined to the territory of Nigeria as it soon spread to all the Nigerian border countries. In Cameroon, for instance, the OHCHR documented more than 200 cases of Boko Haram suspects arrested and detained by defence forces in Amchidé, Ashigashia, Bia, Cheripouri and Délé. Numerous witnesses described an incident in which several hundred Boko Haram suspects were taken away in military trucks from Doublei and Magdeme during a raid conducted on 27 December $2014 .{ }^{8}$ According to witness accounts from Amchidé, Bia and Cheripouri, some Boko Haram suspects were handed over by local vigilante groups to the rapid response battalion for the purpose of settling personal scores. Several interviewees stated that those who escaped custody had given bribes. According to Cameroonian authorities, measures were under way to accelerate prosecutions and to release detainees held unlawfully. ${ }^{9}$

Similarly, following attacks by Boko Haram conducted between June and July 2015 in N'Djamena, the Chadian authorities imposed increased security and surveillance measures, affecting civilians, particularly foreigners. For example, OHCHR received reports that security forces, following the attack on N'Djamena on 15 June 2015, had arrested almost 400 foreigners representing 14 nationalities within a period of two weeks at spot

\footnotetext{
${ }^{1}$ Human Rights Committee, general comment No. 29 (CCPR/C/21/Rev.1/Add.11), para. 4.

2 his was emphasized by the Human Rights Committee in its general comments no. 29 (CCPR/C/21/Rev.1/Add.11) and No. 35 $(\mathrm{CCPR} / \mathrm{C} / \mathrm{GC} / 35)$

${ }^{3}$ United Nations Human Rights Council (n 40).

${ }^{4}$ Nigerian National Human Rights Commission, "The Baga Incident and the Situation in North-East Nigeria: An Interim Assessment and Report', June 2013.

${ }^{5}$ United Nations Human Rights Council (n 40) 6.

${ }^{6} \mathrm{Ibid}, 6$.

${ }^{7}$ United Nations Human Rights Council (n 40).

${ }^{8}$ Ibid, 13.

${ }^{9}$ United Nations Human Rights Council (40).
} 
checks of identity, during house searches or on the street. ${ }^{1}$

In the Niger, security forces arrested an unspecified number of Boko Haram suspects, including children, in the Diffa region between February and July 2015. In July, for example, 40 juveniles suspected of being members of Boko Haram were reported to have been detained in the prisons of Koutoukale and Kollo. Some were later transferred to the juvenile section of Niamey prison. Since the above-mentioned arrests many family members have been unable to locate their relatives in detention. ${ }^{2}$ For example, of the 200 arrests made by the Cameroonian authorities, OHCHR was able to confirm the location of only 20 of them in the four prisons hosting Boko Haram suspects in Maroua, Kouseri, Mokolo and Yagoua; the whereabouts of the other 180 remains unknown. In addition, non-governmental organizations documented approximately 260 arrests, and OHCHR was able to confirm that only 45 individuals were at the central prison in Maroua. While an official communique issued by the Ministry of External Relations of Cameroon indicated that 25 people had died in detention in Cameroon, 192 are yet to be accounted for. Some witnesses in Nigeria recalled that young men who were Boko Haram suspects were deprived of their liberty by civilian vigilante groups or the army and never seen again; owing to fear of reprisals from either party to the conflict, however, few such incidents are ever reported. ${ }^{3}$

\subsection{Use of Civilian Vigilantes}

The inability of security forces to protect civilians from Boko Haram attacks and the deterioration of the security situation have led to the emergence of local self-defence groups, known as vigilantes, in north-east Nigeria and Cameroon. In both cases, the vigilantes seem to operate with the tacit approval of the security forces, and it appears that, in both countries, the authorities benefited from the activities of the groups against Boko Haram.

In Maiduguri, north-east Nigeria, the Civilian Joint Task Force or Kato da Gora ("man with a stick") emerged in early 2013, north-east Nigeria, and is often described as a self-help/self-defence interest group. OHCHR received information on abuses committed by the Task Force. ${ }^{4}$ OHCHR learned that the Civilian Joint Task Force has assisted Nigerian security forces in identifying and arresting Boko Haram suspects, controlling security checkpoints, providing information and monitoring the movement of people, and has also used firearms against Boko Haram in self-defence and to safeguard communities.

The OHCHR also received information on allegations of beatings, detention of suspects, bribery, food deprivation, killings and the recruitment of children by the Task Force, despite the advisory issued by the Government on 21 January 2015 on the prohibition of the use or abuse of children and young persons in counterinsurgency efforts in the north-eastern States. Some falsely-identified Boko Haram suspects were allegedly killed by the Task Force, including, in at least one case, a person with a disability. It must be conceded that youthful exuberance and absence of military training often result in jungle justice and human rights abuses due to their overzealousness and youthful exuberance. ${ }^{5}$ The Borno State Commissioner for Women Development and Poverty Alleviation narrated that she and her aides would have been lynched by the Civilian Task Force who mistook them for Boko Haram members, if not for God's intervention. ${ }^{6}$

Some interviewees informed OHCHR that the Civilian Joint Task Force had brought security and order to communities, while others, including children, stated that they felt under pressure from peers to join them or to risk being considered Boko Haram suspects. In areas such as Bama, a witness noted that "entire communities, especially young and unmarried men and boys, joined the Civilian Joint Task Force. ${ }^{7}$ People were afraid to talk about Boko Haram, because they would kill them. The army would also kill you if you didn't cooperate with them." Many Task Force members in Baga and others thought to be members of Boko Haram were reportedly killed in retaliatory attacks when Boko Haram captured the town. In Cameroon, similar vigilante groups were in place before Boko Haram attacks. They have been supported by national authorities and have played a similar role in reporting Boko Haram suspects or suspicious behaviour, and enforcing curfews. ${ }^{8}$

\subsection{Economic and Social Rights and Freedom of Religion}

Motorcycle bans in Cameroon and the Niger have limited the movement of teachers and school children. The already fragile economic situation in some parts of the affected areas has been exacerbated by security and counterinsurgency measures of the Government, such as by those limiting the circulation of traffic or those leading to the closure of borders, motorcycle bans, curfews, the suspension of fishing and the seizure of truckloads of goods, on the grounds that they may be intended for Boko Haram.

Consequently, many people have been deprived of their means of subsistence. The insurgency has also

\footnotetext{
${ }^{1}$ United Nations Human Rights Council (n 40) 14.

${ }^{2}$ Ibid.

${ }^{3}$ Ibid.

${ }^{4}$ United Nations Human Rights Council (40).

${ }^{5}$ United Nations Human Rights Council (n 40).

${ }^{6}$ Ibid.

${ }^{7}$ United Nations Human Rights Council (n 40) 15

${ }^{8}$ Ibid.
} 
exacerbated tensions between communities and religions and increased the risk of further violence among communities. In July 2015, the Governments of Cameroon and of Chad banned the wearing of full-face veils following successive suicide bomb attacks by veiled women and girls, possibly raising issues with regard to the freedom of religion or belief.

\section{Conclusion}

This paper has examined the concepts of insurgency, counter-insurgency and human rights violations in Nigeria as well as neighbouring countries where counter-insurgency operations have been carried out against the Boko Haram sect. It established that citizens have certain basic inalienable rights which should not be arbitrarily taken away on the altar of the war against insurgency. Regrettably, the conduct of counter-insurgency campaigns in the Northeast by the Multinational Joint Task Force (MNJTF) has come under criticism due to the human rights abuses alleged to have been committed by the military against civilians. The extra-judicial killing of Mohammed Yusuf, the Boko haram's founder, in police custody in 2009 and the subsequent indiscriminate slaughter of suspected members of the sect has been widely reported, the indiscriminate arrest and detention without trial of suspected Boko Haram insurgents, the enforced disappearance of persons as well as the killing of civilians in the course of counter-insurgency offensives are all instances that lend credence to the fact that the human rights violations is an inextricable component of counter-insurgency campaigns in Nigeria.

It is, therefore, recommended that while emergency rule allows extensive powers on the part of security operatives to effectively contain insurgency in the northeast, it is expected that the security forces should not use emergency powers as a cover to engage in large scale violations of human rights.

\section{References}

'Breaking News: Jonathan Declares State of Emergency in Borno, Yobe and Adamawa State', Sahara Reporters (New York, 14 May 2013 [online] Available http:/www.saharareporters.com/2013/05/14/breakingnews.jonathan-declares-state-of emergency-borno-yobe-and-adamawa-state (February 21, 2019).

$$
\text { An Introduction'. [online] }
$$

Available https://jadl.act.nato.int/NATO/data/NATO/lm_data/lm_8422/11689/index.html (February 21, 2019).

Bureau of Political-Military Affairs, (2009). Department of State.

David, H., and James, F., (2006), "FM 3-24 Counterinsurgency”, 3(33) Marine Corps Warfighting Publication, 12 .

Drew, D., (1988), "Insurgency and Counterinsurgency: American Military Dilemmas and Doctrinal Proposals" in Report No. AU-ARI-CP-88-1.

George, W., (2009), Tactics in Counterinsurgency. Washington D.C: Headquarters Department of the Army.

Gompert, C., etal, (2008), War by Other Means: Building Complete and Balanced Capabilities for Counterinsurgency. Santa Monica: Rand.

Hellesen, P., (2008), "Counterinsurgency and Its Implications for the Norwegian Special Operations Forces" (Unpublished Thesis for the Naval Post Graduate School, Monterey, California, USA.

Igwe, O. W., "Terrorism, the Rule of Law and the Nigerian Nation" [online] Available http://www.researchgate.net/profile/Ow_/gwe/publication/275271581_TERRORISM_THE_RULE_OF_LA W AND THE NIGERIAN NATION/links/553658c90cf218056e941]dd8.pdf?origin= (February 21, 2019).

Joint Püblication 1-022, (2005) DoD Dictionary of Military and Associated Terms dated 12 Apr 2001 (amended to 25 August 2005).

Kilcullen, D., (2006), "Three Pillars of Counterinsurgency" in Government Counterinsurgency Conference held in 2006 at Washington [online] A.C. Available http://www.au.af.mil/au/awc/awegate/uscoin3pillars_of_counterinsurgency.pdf (January 19, 2019).

Kraska, B. \& Kappeler, E., (1999), "Militarizing American Police: The Rise and Normalization of Paramilitary Units' in Kappeler, V.E., (ed), The Police and Society: Touchstone Readings. Prospect Heights: Waveland Press.

Lilly, D., (1992), “City Urged to Bury Weed and Seed Plan”, Seattle Times.

Liolio, S.E., (2013), "Rethinking Counterinsurgency: A Case Study of Boko Haram in Nigeria", Austria: Unpublished M.A. Thesis, European Peace University.

Nigerian National Human Rights Commission, (2013), “The Baga Incident and the Situation in North-East Nigeria: An Interim Assessment and Report".

Odomovo, A.S., (2014), "Insurgency, Counterinsurgency and Human Rights Violations in Nigeria", 3 The Age of Human Rights Journal, 6.

Omolaye-Ajilaye, A., (2015), "Legal Framework for the Prevention of Terrorism in Nigeria”, 2 NIJ Law Journal, 38.

Ramraj, V.V. \& Thiruvengadam, A.K., (2008) Emergency Powers in Asia: Exploring the Limit of Legality. London: Oxford University Press. 
Siegel, J., (2007) Criminology: Theories, Patterns and Typologies (11 ${ }^{\text {th }}$ ed.). Belmount, CA: Wadsworth Cengage Learning.

United Nations Human Rights Council, 'Violations and Abuses Committed by Boko Haram and the Impact on Human Rights in the Countries Affected' [Online] Available https://www.ohchr.org/EN/HRBodies/HRCRegularSessions/.../A-HRC-30-36_en/ > (February 20, 2019).

Vrooman, S., (2005), “A Counterinsurgency Campaign Plan Concept: The Galula Compass” in A Monograph, US Army School of Advanced Military Studies, United States Army Command and General Staff College Fort Leavenworth, Kansas (AY 04-05).

Williams, K., (2011), "The Other Side of the COIN: Counterinsurgency and Community Policing", 3 A Journal for Social Movement, 97. 